\title{
Fundamental Dilemmas Concerning the Constitutional Arrangements for the Formation of the Government in the Republic of Slovenia
}

\author{
UDK: $321(497.4)(045)$ \\ Rudi Kocjančič \\ Univerza of Ljubljana, Faculty of Administration \\ rudi.kocjancic@fu.uni-lj.si
}

\begin{abstract}
In Slovenia, even twenty years after the adoption of its Constitution, the amendments to the constitutional arrangements for the appointment of ministers represent one of the fundamental constitutional dilemmas of the political elite and experts on constitutional law. The following two variants are most topical: according to the first variant, following the example of the German constitution, ministers would be appointed by the president of the republic on the proposal of the president of the government, elected by the National Assembly; according to the second variant, the National Assembly would elect the president of the government together with the submitted candidate list of ministers. Nevertheless, the appointment of ministers according to the chancellorship model, which excludes the parliament from any voting on their appointment, i.e. also from the vote of investiture on the government, would undermine their legitimacy and disproportionally strengthen the constitutional position of the president of the government. In contrast, the election of the president of the government together with candidates for ministers would be significantly more transparent and legitimate. However, it will not be possible to form a stable government without changing the electoral system, which systemically causes party fragmentation of the National Assembly.
\end{abstract}

Keywords: parliamentary system, chancellorship model, appointment of ministers, comparative arrangements, electoral system

JEL:KO

Kocjančič, R. (2012). Fundamental Dilemmas Concerning the Constitutional Arrangements for the Formation of the Government in the Republic of Slovenia. Uprava/Administration X(2), 79-87. 


\section{Suspension of the appointment of Ministers in the National Assembly as a deviation from the parliamentary system}

In Slovenia, even twenty years after the adoption of its Constitution, the dilemma of the modification of constitutional arrangements for the appointment of ministers remains highly pertinent. The current arrangements under which ministers are appointed and dismissed by the National Assembly at the proposal of the president of the government (Constitution of the Republic of Slovenia, Article 112, first paragraph) are not comparable with the constitutional arrangements for the appointment of ministers, neither in classic parliamentary systems nor in the German parliamentary government system. On the basis of the prevailing opinion that the appointment of ministers in the National Assembly is neither conceptually nor functionally fully in line with the fundamental principles of the parliamentary system, in 2001, the Slovenian government and a group of deputies lodged two proposals in the constitutional revision process on the modification of constitutional arrangements for the appointment of ministers that remain at the centre of attention of the political and professional public.

On the basis of the opinion that the most suitable model for the preparation of modifications and supplementations of constitutional arrangements for the appointment of ministers is »the chancellorship model«, the Slovenian government proposed that the first paragraph of Article 112 be amended so as to read: "Ministers are appointed and dismissed by the president of the republic on the proposal of the president of the government. " ${ }^{1}$

Before adopting a stance on the government's proposal, we have to present the «chancellorship model " of German government formation from both developmental and problem identification perspectives. In the draft Basic Law or the German Constitution, the Constitutional Commission of the Parliamentary Council proposed that following the example of the classic parliamentary system, which also includes the vote of the investiture on the government, the federal president would appoint the federal chancellor, and on the latter's proposal federal ministers. However, after subsequent thorough discussions, it proposed to the parliamentary council that the Bundestag, at the proposal of the federal president, elect the federal chancellor while the federal president, at the proposal of the federal chancellor appoints federal ministers(Hermes, 1998, pp. 1209-1210.). In the evaluation of the Constitutional Commission, the view prevailed that Germany, due to negative experiences with unsteady governments in the period of the Weimar Constitution, had to limit the powers of the federal president and strengthen the role of the Bundestag and government, and especially the powers of the federal chancellor (von Beyme, 2004, p. 261).

1 Proposal for the beginning of the procedure for modification of the Constitution of the Republic of Slovenia with a draft Constitutional Act, Bulletin of the National Assembly of the Republic of Slovenia No 69/2001 of 6 August 2001, p. 18. 
As can be seen from its various basic models as well as from its lengthy discussions, the Constitutional Commission itself already had certain reservations on the adopted constitutional arrangements for the formation of federal government. Prominent constitutional legal experts, who otherwise emphasize the historic and political context in which the constitution was adopted, also consider that the constitutional arrangements for the appointment of federal ministers are not compatible with the fundamental principles of the parliamentary system. Roman Herzog, for instance, in one of his prominent commentaries on the German constitution, considers the appointment of federal ministers on the proposal of the federal president without any participation of the Bundestag as a »breach» (Durchbrechung) of fundamental principles of parliamentarism (Herzog, 1993, Article 62, MN 76). Fritz Münch (1954, pp. 159-160) even considers such a procedure of appointing Federal Ministers to be an "aversion (Abwendung) of the parliamentary system. Even in the Slovenian professional literature we can read a critical observation that »the German chancellor essentially forms the government himself, while the Bundestag does not participate with any kind of voting, it only elects the chancellor himself, even without the government for that matter« (Krivic, 2002, p. 281).

In the explanation of its proposal, the Slovenian Government refers to the "chancellorship « arrangements for the appointment of federal ministers, which was, however (as already pointed out) adopted in the social and political context in the post-war Germany as a pragmatic compromise. In doing so, it underestimates the principle of sovereignty of the people, according to which the parliament in the parliamentary system is the source of the democratic legitimacy of the government, while at the same time it overestimates the importance of the principle of separation of powers in the process of government formation. A fundamental difference between the constitutional arrangements of government formation in the classic parliamentary system and the German parliamentary government system, as it is consistently designated in German literature, lies in the fact that classic governments are based on vote of investiture, while the German federal government is based only on the investiture vote on the federal chancellor (Hermes, 1998, p. 1188). The potential suspension of the appointment of ministers in the National Assembly would thus limit the democratic legitimacy of the government and at the same time recognize the »chancellor position« of the president of the government in its formation.

Given that the Slovenian parliamentary system does not use the instrument of investiture vote and that the government's proposal does not foresee any other form of vote in the National Assembly on support to the ministers, the suspension of vote on the appointment of ministers in the National Assembly would be a deviation from the parliamentary system. 


\section{Comparative presentation of simultaneous voting on the election of the president of the government and on the candidate list of ministers in the National Assembly}

According to the proposal of a group of deputies, which was lodged in the constitutional revision process in 2001, the appointment of ministers in the National Assembly would be retained, but in the framework of modifications of the constitutional arrangements for the formation of the government as a whole. The group prepared the contents of the proposal with some minor modifications on the basis of a professional draft prepared by Peter Jambrek and Gregor Virant in 2000 within the framework of the government of Andrej Bajuk. $^{2}$

According to this proposal, the second paragraph of Article 111 would be amended so as to read: »The president of the government together with the submitted candidate list of ministers is elected by the National Assembly by a majority vote of all deputies unless otherwise provided by this constitution." Voting would be public. The National Assembly would vote on the election of the president of the government together with the candidate list of ministers, also in the potential second and third rounds, while following unsuccessful second or third vote the president of the republic would dissolve the National Assembly and call new elections.

While the professional public welcomed the proposal, considering it a search for constitutional possibilities for a more rational formation of the government, part of the public was explicitly critical towards the central part of the proposal according to which the National Assembly would vote on the election of the president of the government together with the candidate list of ministers. In a particularly critical opinion, it was stated that the proposal, in line with which the National Assembly would vote on the formation of the government "at one time», is both in principle and in practice incompatible with the formation of the government in the parliamentary system, in which in the first phase, the head of state forms the government on the basis of different procedures, while in the second phase, the parliament as a rule votes on the government's investiture vote (cf. Krivic, 2001, pp. 85-86).

Compared to traditional procedures of the formation of parliamentary governments, the proposal was indeed surprising, but simultaneous voting on the formation of government as a whole had already been introduced in some newer constitutions, including those of the Republic of Serbia and the Republic of Montenegro. Thus, the Serbian constitution states: »The National Assembly shall simultaneously vote on the government's programme and election of the prime minister and members of the government« (Article 127, third paragraph). The constitution of Montenegro includes a substantively

2 Proposal for the beginning of the procedure for modification of the Constitution of the Republic of Slovenia with a draft Constitutional Act, Bulletin of the National Assembly of the Republic of Slovenia No 1/2002 of 9 January 2002, p. 16.

82 Administration, Vol. X, No. 2/1012 
identical provision: "The parliament shall decide simultaneously on the program of the formateur and the proposal for the composition of the government« (Article 103, third paragraph; cf. Šuković, 2009, pp. 32-33). According to both constitutions, the president of the republic, logically, proposes a candidate for the prime minister or the formateur.

While the proposal of the group of deputies specifically provides for public vote, the Serbian and Montenegrin constitutions do not lay down the manner of vote, thus allowing for a public vote. As is the case with the proposal at hand, a majority vote of all deputies is needed for the election of the president of the government together with its members also according to both constitutions. Two distinct particularities of the Serbian and Montenegrin constitutions are the presentation of the programme, which in Slovenia is covered in the relevant provision of the Rules of Procedure of the National Assembly (Article 226, second paragraph), and the simultaneous vote on the government's programme.

Thus, the Serbian and Montenegrin constitutions have - following the example of the German Constitution - adopted the election of the prime minister in the parliament, and at the same time the Serbian and Montenegrin parliaments vote on the election of the prime minister and the composition of the government. Aleksandar Fira (2007, pp. 70-71), a prominent Serbian constitutional jurist, has designated the Serbian government under its present constitutional arrangements a "chancellor government». The National Assembly, in contrast, votes twice in the process of formation of the government, first on the election of the president of the government, and then on the appointment of ministers.

At the same time, it has to be specifically pointed out that the proposal of the group of deputies foresees that the candidate for the president of the government submits, within seven days, to the National Assembly a proposal for a candidate list of ministers. The Serbian constitution has established that the National Assembly is dissolved if it »fails to elect « the government within 90 days from the day of its constitution (Article 109, third paragraph), while the Montenegrin constitution does not provide for deadlines in the process of government formation. The foreseen seven-day period for the submission of the candidate list of ministers, as proposed by the group of deputies, is certainly too short in a parliamentary system with broad government coalitions, requiring long and complex negotiations on the government programme and the composition of the government itself.

The constitutional arrangements of the formation of government, as proposed by the group of deputies and as defined by the Serbian and Montenegrin constitutions, are also topical and challenging for the constitutional jurists and experts from the wider systemic perspective (cf. Pajvančić, 2009, pp. 163171). Specifically, following the German example, in addition to the election of the president of the government in the National Assembly, a constructive 
vote of no confidence has been adopted in the Slovenian constitution, while the Serbian and Montenegrin constitutions have adopted the classic vote of no confidence in the government. All three constitutions also use the vote of confidence in the government, which is (in addition to the vote of no confidence) the most important constitutional institute for the determination of political responsibility of the government in the parliamentary system. Given that, according to the proposal of the group of deputies, the current vote of no confidence in the government would be maintained with relevant editorial changes, a question arises here of whether the voting on the election of the president of the government together with the submitted candidate list of ministers would not considerably hinder the vote of no confidence in the government. With regard to this consideration, it needs to be stated that the vote on the new president of the government together with the candidate list of ministers would be more demanding, but, at the same time, the vote on the potential new government as a whole would be more transparent, as it would also enable easier assessment of the qualifications of both the candidate for the president of the government and candidates for ministers. In comparison with the current constitutional and procedural (and partly also legal) arrangements of the formation of the government, in the framework of which the National Assembly votes on its formation twice, even with the support of various coalitions, the vote in the National Assembly on the election of the president of the government together with the candidate list of ministers would be more rational, and, above all, more legitimate, than if the president of the republic on the proposal of the president of the government would appoint the ministers, as is the case with the »chancellorship method «.

\section{Government formation and functioning, and the electoral system}

Although in the current political situation there are no real possibilities for the modification of the constitutional arrangements of the electoral system, one cannot ignore the fact that the electoral system significantly affects the composition of the National Assembly in terms of political parties, while indirectly also the formation and functioning of the government. According to Slovenian constitutional arrangements, the main elements of the electoral system are proportional representation, a four-percent threshold required for election to the National Assembly and voters' decisive influence on the allocation of seats to the candidates (Constitution of the Republic of Slovenia, Article 80, fifth paragraph) (Grad, 2009, pp. 1728-1731). However, even after the introduction of a higher threshold for election to the National Assembly, seven or eight political parties entered the National Assembly in all elections held so far. At the same time, the personalisation of elections actually has an ambivalent function: in the majority electoral system, it leads to the polarisation of votes, while in the proportional system to the dispersion of votes. The introduction of the personalisation of elections in this extent was more of a 
political concession in the process of the adoption of the Constitutional Act rather than a possibility for systemic strengthening of the role of voters in elections. The Constitutional Act does not allow major corrections towards the majority electoral system; therefore, the door through which political parties enter the National Assembly still remains relatively open, which also indirectly hinders the formation of the government and weakens its stability. ${ }^{3}$

In comparison with the Slovenian proportional electoral system, Germany (by means of a federal law on elections) introduced a combined electoral system comprising the advantages of both the majority electoral system as well as the proportional electoral system. According to the abovementioned law, each voter has two votes; with the first vote, he directly casts a vote according to the system of relative majority for a constituency representative in his electoral district (Article 5), while he casts a second vote according to the purely proportional system for the regional party list (Article 6), the number of seats allocated to individual parties being counted on the basis of votes, received on a federal basis; therefore, it would be more correct to call this system a personalised proportional electoral system. When allotting the seats in the legislature, only parties that have won at least $5 \%$ of the nationwide vote are taken into account. Such an electoral system prevents unreasonable party fragmentation of the parliament as well as enabling a relatively rapid formation of the government and its stability. A so-to-speak exotic difference between the Slovenian and German parliaments, which mainly stems from different electoral systems, is figuratively visible particularly in the fact that in the Slovenian 90-member National Assembly, there are seven or eight political parties plus two representatives of national indigenous ethnic minority communities, while in the 656-member German Bundestag, there are, as a rule, two stronger and two weaker political parties.

In Germany, where high concentration of parliamentary parties is, as a rule, the result of the electoral system, the federal president has thus far proposed the leader of the party coalition that won the parliamentary elections for the federal chancellor. With the exception of Helmut Kohl, who was elected Federal Chancellor on the second ballot in 1983 due to rapid dissolution of the government coalition, all other federal chancellors over the past 60 years were elected on the first ballot. In contrast, the president of the Republic in Slovenia, due to the distinct party fragmentation of the National Assembly, sometimes (such as after the recent early elections) has difficulties when evaluating which parties could form a government coalition that would support the election of his candidate for the president of the government.

In addition, the stability of the German government is not based as much on the constructive vote of no confidence, but rather on the high level of concentration guaranteed by the electoral system and the relatively solid party structure of the Bundestag that does not allow a large number of

3 On the conflict of the Constitutional Act with legal matters see Kaučič (2007, pp. 54-57). 
Rudi Kocjančič

coalitions (Hesse, 1995, p. 150; Hofmann \& Perger, 1992, p. 240; Hermes, 1998, p. 1272; von Beyme, 2004, p. 90). At the same time, it is paradoxical that the constructive vote of no confidence can also strengthen the stability of unsuccessful governments. In Slovenia, for instance, it can happen that the government loses the support in the National Assembly, yet due to party fragmentation it is not possible to form a party coalition that could form a new government on the basis of the constructive vote of no confidence.

The twenty-year-long parliamentary practice demonstrates that even by means of potential changes in the constitutional arrangements, it will not be possible to ensure a stable government and its streamlined functioning without changing the electoral system. With regard to changes in the electoral system, emphasis should be given to unequivocal advantages of proportional and majority electoral systems while forsaking weaknesses of both kinds of electoral systems (Ribičič, 2001, pp. 221-222). Of course, the issue of changes to the electoral system is a political issue par excellence.

Prof. dr. Rudi Kocjančič je nosilec predmeta ustavno pravo na Fakulteti za upravo $\checkmark$ Ljubljani. Je tudi član več uredništev znanstvenih in strokovnih revij. V letu 1991 je bil član delovne skupine za lokalno samoupravo in član delovne skupine za ustavnost in zakonitost pri Ustavni komisiji za strokovno pripravo Ustave Republike Slovenije. Je tudi podpredsednik Društva za ustavno pravo Slovenije. 
Fundamental Dilemmas Concerning the Constitutional Arrangements for the Formation of the Government in the Republic of Slovenia

\section{References}

- Beyme, K. (2004). Das politische System der Bundesrepublik Deutschland, 10. aktualisierte Auflage. Wiesbaden: VS Verlag für Sozialwissenschaften GWVFachverlage $\mathrm{GmbH}$.

- Fira, A. (2007). Ustavno pravo Republike Srbije. Novi Sad: Fakultet za pravne i poslovne studije.

- Grad, F. (2009). Razsežnosti ustavne določitve volilnega sistema. Dnevi slovenskih pravnikov 2009, Portorož, 15.-17. oktober. Podjetje in delo 35(6-7). Ljubljana: GV založba.

- Hermes, G. (1998). V: Dreier, H. (ur.). Grundgesetz-Kommentar, Band II. Tübingen: Mohr Siebeck.

- Herzog, R. (1993). V: Maunz, T., Dürig, G. \& Herzog, R. (ur.). GrundgesetzKommentar. München: Verlag C. H. Beck.

- Hesse, K. (1995). Grundzüge des Verfassungsrechts der Bundesrepublik Deutschland. Heidelberg: C.F. Müller.

- Hofmann, G. \& Perger, W. A. (1992). Die Kontroverse. Weizsäckers Parteienkritik in der Diskussion. Frankfurt: Eichborn Verlag.

- Kaučič, I. (2007). Neposredna demokracija in volilni sistem. V: Bavcon, L. et al. (ur.). 15 let uresničevanja Ustave Republike Slovenije. Ljubljana: Pravna fakulteta.

- Krivic, M. (2001). Po desetih letih - iz ene skrajnosti v drugo? Skrajnost pri volitvah/imenovanju ministrov. VII. dnevi javnega prava, Portorož.

- Krivic, M. (2002). Formiranje vlade: drugi predlog - nestrokovna improvizacija. VIII. dnevi javnega prava, Portorož.

- Münch, F. (1954). Die Bundesregierung. Frankfurt am Main: Metzner.

- Pajvančić, M. (2009). Komentar Ustava Republike Srbije. Beograd: Fondacija Konrad Adenauer.

- Ribičič, C. (2001). Uravnoteženost političnega zastopstva v parlamentu. VII. dnevi javnega prava, Portorož. Ljubljana: Inštitut za javno upravo.

- Šuković, M. (2009). Tri različita ustavna uređenja Crne Gore. Od razbijanja šestočlane jugoslovenske federacije (1992.) do sada (2009.). Revus - Revija za evropsko ustavnost 11, 9-43. 